\title{
THE IMPLEMENTATION STUDY OF STORING AND REPORTING OF NARCOTICS AND PSYCHOTROPICS AT PHARMACIES IN DENPASAR CITY, BALI PROVINCE
}

\author{
I Made Arie Dharma Putra Nugraha ${ }^{1}, K_{\text {Kadek Hendra }}^{2}$, I Made Agus Gelgel Wirasuta ${ }^{1 *}$ \\ ${ }^{1}$ Department of Pharmacy, Faculty of Math and Science, Udayana University \\ ${ }^{2}$ Faculty of Pharmacy, Universitas Gadjah Mada, Yogyakarta
}

Corresponding author email: gelgel.wirasuta@unud.ac.id

\begin{abstract}
Introduction: Storage and reports of narcotics and psychotropic in pharmacy must be carried out according to standard operating procedures which are based on legislation on maintaining safety, efficacy, and quality of the drugs. Objective: This study aimed to observe the implementation process of narcotics and psychotropic storing and reporting in accordance to the law in force in several pharmacies in Denpasar City. Methods: Five biggest pharmacies located in Denpasar City were picked by purposive sampling method. This study used a descriptive observational method to provide a brief overview of the term and condition of narcotics and psychotropic storing and reporting that implemented in real-time in the pharmacies. Results: Overall, the study revealed that the majority of pharmacies were successfully in term of fulfilling the various aspects of narcotics and psychotropic storing and reporting, including the storage of drugs at the special cabinets, in special the implementation process of narcotics and psychotropic that cited in the Regulation of The Minister of Health of the Republic of Indonesia Number 73 of conditions according to safety and stability, FEFO and FIFO systems, manual and electronic stock cards system, separation of damaged and/or expired drug, inventory stock, and compliance and completeness of reporting using SIPNAP. Conclusion: Responsible pharmacist must always evaluate the storage and reporting of narcotics and psychotropic in the pharmacy to guarantee quality and maintain suitability of the pharmaceutical services process according to established standards.
\end{abstract}

Keywords: forensic pharmacy, storing and reporting, narcotics and psychotropic, legislation

\section{INTRODUCTION}

Pharmacists who involved in the pharmaceutical practice should stick to the forensic pharmacy. The term of forensic in pharmaceutical field is known as "the application of science to the law" ${ }^{[1]}$. Science in forensic pharmacy is the base for determining the reason for an event to occur. Whereas law acts as a regulation to society, for instance regulating social communities to run their rights and obligations. All fields in forensic pharmacy have their respective roles and are not only related to handle legal issues, but also regulate themselves as pharmacist. Forensic pharmacy was better to be applied by every pharmacists to build awareness related to the task performed, which was revealed in pharmaceutical services.

The progression of pharmaceutical services by pharmacists now has experienced a shift in mindset, which initially focused on quality assurance of pharmaceutical preparations (product oriented) to pharmaceutical care which 
prioritizes patients (patient oriented) ${ }^{[2]}$. Pharmaceutical services must be carried out by a pharmacist in order to reach the patient safety. The implementation of pharmaceutical services should guarantee the quality and evaluate periodically in order to prevent the occurrence of drug irregularities and maintain the suitability of the pharmaceutical services process according to established standards ${ }^{[3]}$.

Specific aspect which is evaluated in term to ensure the quality of pharmaceutical services, focussed on the storage and reporting of narcotics and psychotropics. Storage and reporting of narcotics and psychotropics must be considered because the number of narcotics and psychotropics abuse that BNN (National Narcotics Agency) has successfully disclosed in Indonesia has increased significantly. Based on the data from the Indonesian Ministry of Health, the average percentage increase of narcotics and psychotropics cases from 2012 to 2016 was $76.53 \%$. The highest increase in the number of cases occurred in 2013 to 2014 , which was $161.22 \%$ (147 cases in 2013 and 384 cases in 2014). ${ }^{\text {[2] }}$ Bali Province in the period 2012 to 2016 always occupied the top 10 position in the number of narcotics and psychotropics cases in Indonesia, and Denpasar City always held the first position in the number of narcotics and psychotropics cases in Bali Province ${ }^{[23]}$.

Based on the Regulation of Ministry of Health of The Republic of Indonesia Number 3 of 2015 on Circulation, Storage, Destruction, and Reporting of Narcotics, Psychotropic and Pharmacy Precursors encourages the pharmacists at the pharmacy have a proper storage specifically for narcotics and psychotropic as well as able to maintain the safety, efficacy, and quality of narcotics and psychotropic as stated in the SOP (Standard Operating Procedure). A special storage area intended to be a special storage cabinet, both for narcotics and psychotropic which took separately. Special cabinets that are owned by pharmacy must meet various requirements such as made by strong materials; not easy to move and has minumum two different keys; must be placed in a safe place that is not visible for everyone, for a variety of pharmaceutical service facilities including pharmacies, and special cabinet keys are controlled by the responsible pharmacist in charge and other authorized personnels. The storage of narcotics and psychotropic also considering the risk analysis operated by the pharmacists, especially in term of facilitating the supervision of these classes of. Narcotics and psychotropic which reported in pharmacies, the standard operating procedures are classified as electronic external reporting through SIPNAP, an national online drug application, by reporting several aspects include names, dosage forms, and the strength of narcotics and psychotropic; total beginning and ending of the inventory month; amount received; as well as the amount submitted ${ }^{[4]}$. Therefore, the process of storing and reporting narcotics and psychotropic by pharmacists in the pharmacies as visualitation of pharmaceutical services must be implemented refered to the Regulation of The Minister of Health of the Republic of Indonesia Number 73 of 2016 on Pharmaceutical Service Standards at The Pharmacy.

This study aimed to observe the implementation process of narcotics and psychotropic storing and reporting in accordance to the law in force in several pharmacies in Denpasar City. The correlation between implementation of narcotics and psychotropic storaging and reporting at the pharmacy with operated standard, which was expected to improve patient safety was expected through this study. 


\section{METHODS}

\section{Material and Equipment}

The sample in this study is five biggest pharmacies located in Denpasar City which determined by purposive sampling method. These five biggest pharmacies are divided into four chain pharmacies and one independent pharmacy. The instruments used in this study were the observational sheet by direct observation of the sample and record the conditions in the real condition in accordance with the observation sheet that was compiled.

\section{Study Design}

The operational limitation in this study is to refer to the provisions of the Regulation of The Minister of Health of The Republic of Indonesia Number 3 of 2015 on Circulation, Storage, Destruction, and Reporting of Narcotics, Psychotropic and Pharmacy Precursors; Regulation of The Indonesian Food and Drug Authority Number 4 of 2018 on Supervision of the Management of Medicines, Medicines, Narcotics, Psychotropic, and Pharmaceutical Precursors in Pharmaceutical Services Facilities and the Regulation of The Minister of Health of The Republic of Indonesia Number 73 of 2016 on Pharmaceutical Service Standards at the Pharmacy. The data collection was done descriptively observational which was carried out in June 2020 on five pharmacies. Observations included the implementation of pharmaceutical service practices in the form of narcotics and psychotropic storage by pharmacists in pharmacies, and external reporting through the SIPNAP system. Results were nominated, tabulated and displayed as descriptive data.

\section{RESULT AND DISCUSSIONS}

Pharmacy in Denpasar City which is observed in carrying out the narcotics and psychotropic storage and reporting process generally based on the provisions of the
Regulation of The Ministy of Health of The Republic of Indonesia Number 3 of 2015 on Circulation, Storage, Destruction, and Reporting of Narcotics, Psychotropic and Pharmacy Precursors; Regulation of The Indonesian Drug and Food Authority Number 4 of 2018 on The Supervision of The Management of Medicines, Narcotics, Psychotropic, and Pharmaceutical Precursors in Pharmaceutical Services Facilities and the Regulation of The Minister of Health of The Republic of Indonesia Number 73 of 2016 on Pharmaceutical Service Standards at The Pharmacy. Various components in the implementation of Narcotics and Psychotropic Storage and Reporting, in the form of storage, storage conditions, expenditure system, recording on a manual or electronic stock card, separation of expired drugs, inventory stock, reporting compliance every month, to the completeness of reporting must be observed and obeyed. The implementation of various components in the storage and reporting of narcotics and psychotropic are depicted in Table 1 and Table 2 respectively.

The narcotics and psychotropic storage and reporting process is presented in Figure 1 and Figure 2 respectively. The storage of narcotics in pharmacy is carried out after narcotics and psychotropic received have been checked for physical compatibility between narcotics and psychotropic drugs received with those ordered, including checking expired date. The narcotics and psychotropic storage begins with the process of recording the data in a manual stock card, and continue with electronic recording on a computer system at the pharmacy. The narcotics and psychotropic that have been recorded are stored in a medicine box in a special cabinet. Narcotics and psychotropic will be compiled and issued with a FIFO (First Expired First Out) or FIFO (First In First Out) system depending on the expired date of narcotics and psychotropic. 
Table 1. Observational Results of Narcotics and Psychotropic Storage in Some Pharmacies in Denpasar City

\begin{tabular}{|c|c|c|c|}
\hline \multirow{2}{*}{ No. } & \multirow{2}{*}{ Evaluation Variables } & \multicolumn{2}{|c|}{ Suitability } \\
\hline & & Total & $\%$ \\
\hline 1. & The narcotics and psychotropics storage area is a special cabinet & 5 & 100 \\
\hline \multirow[t]{6}{*}{2.} & Special cabinet requirements: & & \\
\hline & a. Made from strong material & 5 & 100 \\
\hline & b. Not easy to move & 5 & 100 \\
\hline & c. Having 2 (two) different keys & 5 & 100 \\
\hline & d. Put it in a safe place and not visible to the public & 5 & 100 \\
\hline & $\begin{array}{l}\text { e. Special cabinet keys are controlled by the pharmacist in charge/the } \\
\text { appointed pharmacist and other authorized employees }\end{array}$ & 5 & 100 \\
\hline 3. & $\begin{array}{l}\text { Narcotics storage places are prohibited from being used to store goods } \\
\text { other than narcotics }\end{array}$ & 5 & 100 \\
\hline 4. & $\begin{array}{l}\text { Psychotropics storage places are prohibited from being used to store goods } \\
\text { other than psychotropics }\end{array}$ & 5 & 100 \\
\hline 5. & $\begin{array}{l}\text { All drugs/ingredients medicines must be stored in suitable conditions so } \\
\text { that their safety and stability are guaranteed }\end{array}$ & 5 & 100 \\
\hline 6. & $\begin{array}{l}\text { Drug expenditure using the FEFO (First Expired First Out) and FIFO (First } \\
\text { In First Out) systems }\end{array}$ & 5 & 100 \\
\hline \multirow[t]{9}{*}{7.} & \multirow{9}{*}{$\begin{array}{l}\text { Equipped with a stock card manual with completeness: } \\
\text { a. Names, dosage forms, and strengths of narcotics and psychotropics } \\
\text { b. Amount of stock } \\
\text { c. Date, document number, and source of receipt } \\
\text { d. Amount received } \\
\text { e. Date, document number, and purpose of delivery } \\
\text { f. Amount submitted } \\
\text { g. Batch number and expiration of each receipt or submission } \\
\text { h. Initials or identity of the designated officer }\end{array}$} & & \\
\hline & & 5 & 100 \\
\hline & & 5 & 100 \\
\hline & & 5 & 100 \\
\hline & & 5 & 100 \\
\hline & & 5 & 100 \\
\hline & & 5 & 100 \\
\hline & & 5 & 100 \\
\hline & & 5 & 100 \\
\hline \multirow[t]{4}{*}{8.} & \multirow{4}{*}{$\begin{array}{l}\text { Equipped with electronic recording, then: } \\
\text { a. Must be validated, traceable and can be demonstrated when needed } \\
\text { b. Must be able to trace mutation information, at least the last } 5 \text { (five) } \\
\text { years } \\
\text { c. Another recording system must be available which can be seen } \\
\text { whenever needed } \\
\text { d. It must be able to be copied and/or printed out }\end{array}$} & 3 & 60 \\
\hline & & 3 & 60 \\
\hline & & 3 & 60 \\
\hline & & 3 & 60 \\
\hline 9. & $\begin{array}{l}\text { Damaged and/or expired narcotics and psychotropics must be stored } \\
\text { separately from appropriate narcotics and psychotropics, in special } \\
\text { narcotics storage cabinets or psychotropics special storage cabinets and } \\
\text { clearly marked }\end{array}$ & 5 & 100 \\
\hline 10. & $\begin{array}{l}\text { Carry out stock of narcotics and psychotropics stocks regularly at least } \\
\text { once in } 1 \text { (one) month }\end{array}$ & 5 & 100 \\
\hline
\end{tabular}

Table 2. Observation Results of Narcotics and Psychotropic Reporting in Some Pharmacies in Denpasar City

\begin{tabular}{|c|c|c|c|}
\hline \multirow{2}{*}{ No. } & \multirow{2}{*}{ Evaluation Variable } & \multicolumn{2}{|c|}{ Suitability } \\
\hline & & Total & $\%$ \\
\hline 1. & $\begin{array}{l}\text { Pharmacy is obliged to make, store, and submit reports on income and } \\
\text { delivery/use of narcotics and psychotropics, every month to The Head } \\
\text { of District/City Health Service with a copy to The Local Head of } \\
\text { Regional Office. }\end{array}$ & 5 & 100 \\
\hline 2. & $\begin{array}{l}\text { Reporting consists of: } \\
\text { a. Names, dosage forms, and strengths of narcotics and psychotropics } \\
\text { b. Total beginning and end of the month inventory }\end{array}$ & 5 & 100 \\
\hline & c. Amount received & 5 & 100 \\
\hline & d. Amount submitted & 5 & 100 \\
\hline & & 5 & 100 \\
\hline
\end{tabular}




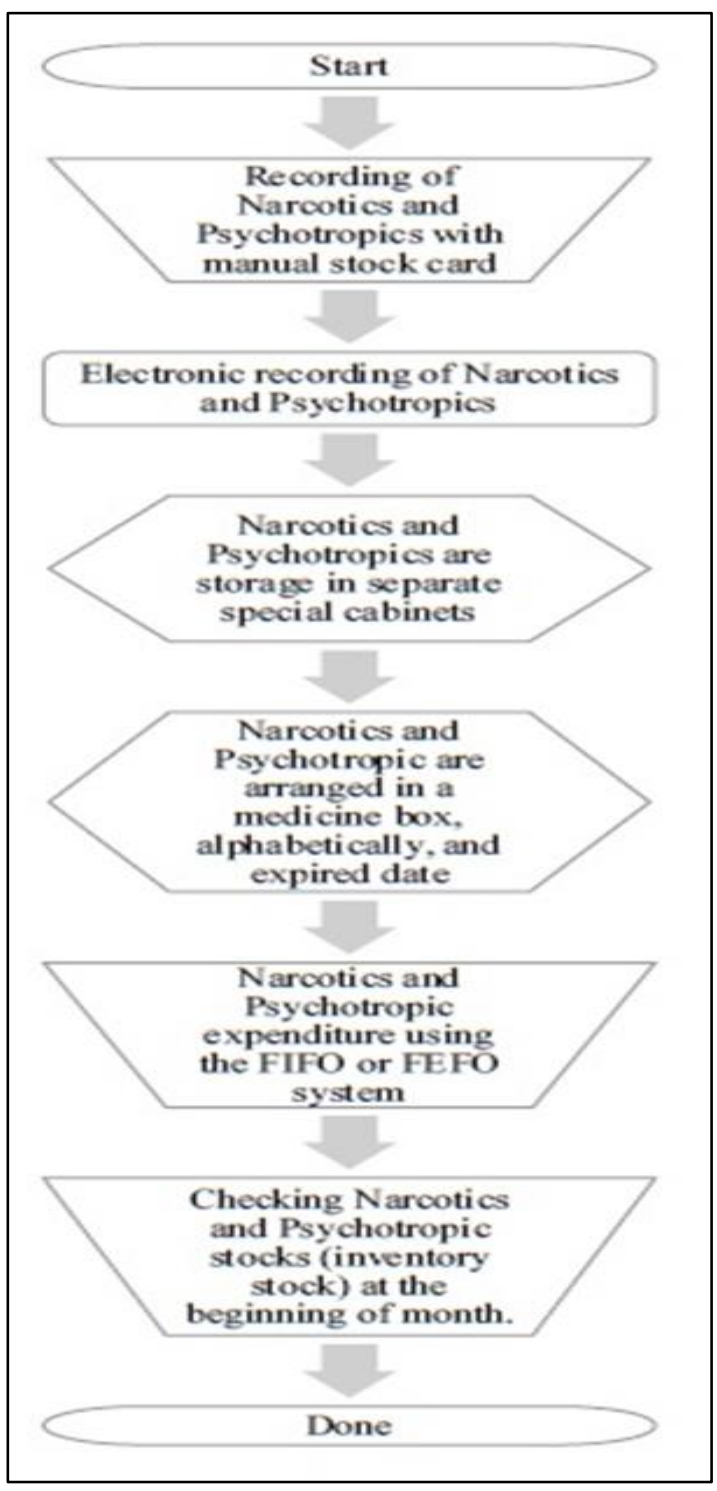

Figure 1. Narcotics and Psychotropic Storing Process

During narcotics and psychotropic storage, drug conditions such as damage must be observed. In addition, the implementation of inventory stock to monitor the suitability of the physical condition of narcotics and psychotropic with existing recording data.

The narcotics and psychotropic reporting process in general at the pharmacy applies SIPNAP (Narcotics and Psychotropics Reporting System). SIPNAP is a system used to report narcotics and psychotropic uses in all pharmaceutical service facilities that will simplify and speed up reporting from The City and District Health Offices to The Central Health Office ${ }^{[15]}$. The narcotics and psychotropic reporting process using SIPNAP is carried out before the 10th of the following month, after checking the suitability of the stock (inventory stock). The reporting process can utilize the excel templates or web form that are available, and the data input process is required according to the records on the card stock manually or electronic records. The reporting process is carried out in stages, starting from preparations to become narcotics, psychotropic, and specifically to morphine/pethidine. After all data entered in the SIPNAP is in accordance, then data transmission to the center in SIPNAP can be done.

First, a place for narcotics and psychotropic storage in the form of a special cabinet. Observation results showed that the five pharmacies that were observed $(100 \%)$ had prepared a place in the form of a special cupboard for narcotics and psychotropic storage. The use of special cabinets in narcotics and psychotropic storing is based to prevent the misuse of each of these classes of drugs because narcotics and psychotropic are stored on open shelves ${ }^{[5]}$. Special cabinets used in the storage of narcotics and psychotropic in each pharmacy are in the form of strong wooden cabinets with security covering a double lock system, and are stored by the responsible pharmacist and the supporting pharmacist. In order to tighten the control of narcotics and psychotropic and avoid misuse, the storage system must be in a separate cabinet. ${ }^{[6]}$ In all pharmacies that were observed resulted in the finding that the placement of special cabinets in narcotics and psychotropic storage was hidden (in the pharmacist's office) and side by side with one another. This is aimed at facilitating the responsible pharmacist in a pharmacy for special cabinets that are used as narcotics and psychotropic storage. In addition, the placement of special cabinets is hidden in order to limit access to the entry and exit of unauthorized staff in pharmacies $^{[20]}$. The size of the special 
cabinets used will be adjusted to the stock of narcotics and psychotropic stored at the pharmacy. In some pharmacies that were observed, it was found that the size of a special ward of psychotropics would be greater because the stock of psychotropics stored was more than narcotics. In a special cabinet, consisting of an outer door and an inner door (double lock) that is useful to increase security in the storage of narcotics and psychotropic ${ }^{[21]}$.

Second, the condition of narcotics and psychotropic storing which guarantees safety and stability. Observation results show that the five pharmacies that were observed (100\%) have prepared storage conditions that can guarantee the safety and stability of narcotics and psychotropic. Special cabinets used in narcotics and psychotropic storage must be clean, free from accumulation of dirt, dry matter, and maintained in acceptable temperature and humidity for each narcotics and psychotropic drug. Storage conditions of narcotics and psychotropic in special cabinets must pay attention to the labeling listed on the packaging, based on the results of the stability of narcotics and psychotropic tests that have been evaluated by the pharmaceutical industry. The applicable Indonesian Pharmacopoeia requirements relating to the storage of each preparation to become narcotics and psychotropic must be implemented to ensure the stability of the drug during storage $^{[7]}$.

Conditions for temperature and humidity in narcotics and psychotropic storing should be at room temperature or controlled room temperature according to Indonesian Pharmacopoeia. Based on the Indonesian Pharmacopoeia Fifth Edition, the intended room temperature is no more than $30^{\circ} \mathrm{C}$. The intended controlled room temperature is maintained thermostatically between $20^{\circ} \mathrm{C}$ and $25^{\circ} \mathrm{C}$, with storage tolerances between $15^{\circ} \mathrm{C}$ and $30^{\circ} \mathrm{C}$. Narcotics and psychotropic drugs must also be stored in a special cabinet that is able to protect from direct light exposure ${ }^{[8]}$. Storage of narcotics and psychotropic at room temperature will be appropriate in the storage of finished preparations in the form of tablets, syrups, and tubes for rectal use, but it is necessary to remember again to check the appropriate storage information in labeling.

Conditions of temperature and humidity in the process of storage of narcotics and psychotropic become one of the factors that must be considered in order to maintain the quality of a narcotics and psychotropic preparations, while maintaining patient safety aspects during the use of narcotics and psychotropic. Temperature and humidity will affect the physical stability of the preparations to become narcotics and psychotropic. If the temperature and humidity of the storage process are not suitable, then a chemical degradation process or physical changes in the preparation can occur and affect the quality and quantity of active substances in the finished preparations narcotics and psychotropic $^{[9]}$.

Third, the narcotics and psychotropic expenditure system used FEFO and FIFO systems. Observation results showed that the five pharmacies observed $(100 \%)$ have implemented FEFO and FIFO systems. In general, the FIFO and FEFO systems in their application at the pharmacy will place preparations to become narcotics and psychotropic with different expiration dates at different locations. For example, narcotics or psychotropic with expiration dates faster will be placed in the outermost, topmost, or frontmost position so that it is easier to reach and can exit first. ${ }^{[10]}$ This is important because the longer the process of storing a drug, such as narcotics and psychotropic, will have a reduced strength or potential, and the effectiveness of use decreases with the expiration time ${ }^{[13]}$.

The application of the FIFO or FEFO system in pharmacies in the storage of narcotics and psychotropic will benefit the pharmacy itself, because it is able to avoid 
the risk of damage to narcotics and psychotropic, and to avoid the possibility of high narcotics and psychotropic drugs that are stored beyond the expiry deadline that has been set on packaging ${ }^{[11]}$. In each pharmacy, prevention of expiration time is fast on narcotics and psychotropic is done by requiring an expired date on narcotics and psychotropic received at least 1 year at most. Thus, the quality of narcotics and psychotropic stored in the pharmacy will be guaranteed so that the main target in pharmaceutical services in the form of patient safety will be achieved.

Fourth, the stock card. Observation results showed that among five pharmacy observed, three pharmacies $(60 \%)$ had implemented the process of recording electronically and recording using a manual stock card, while two pharmacies (40\%) only applied the process of recording using a manual stock card. The use of an electronic recording system has the advantage of a process that is considered more efficient and effective in terms of time. In the manual system, the accuracy of a pharmacist is needed so that the process of recording on a stock card will take longer. Electronic records will help in improving quality related to drug management, especially narcotics and psychotropic in pharmacies $^{[18]}$. In practice, the use of a combination of the two types of recording, either using the manual stock card or electronically using the computer system is preferred. This is based if a discrepancy is found between the physical stock of narcotics and psychotropics in a special cabinet with one of the records, such as the manual recording of the stock card, the difference in the stock that is not recorded can be easily traced in another recording system, namely in the computer system ${ }^{[12]}$. As a data reinforcement to ensure the suitability of recording, it can be seen in narcotics and psychotropics prescriptions stored in pharmacy, making it easier to find errors in recording.

The recording process should be carried out routinely every day, every time there is a mutation process (entry of narcotics and psychotropic, or if any narcotics and psychotropic are damaged or expired). If the recording of narcotics and psychotropic uses a manual stock card, then the stock card must be placed close to the narcotics and psychotropic concerned ${ }^{[12]}$. In practice, there is a mismatch, namely in some pharmacies placing card stock centrally in certain places. This aims to simplify the process of recording on the card stock and prevent damage to the card stock itself.

Fifth, separation of narcotics and psychotropics that are damaged and/or out of date. Observation results show that the five pharmacies $(100 \%)$ have implemented a process of separating damaged and/or outdated narcotics and psychotropic. Specifically in the FEFO system, narcotics and psychotropic which are approaching expiration (3 to 6 months) will be stored separately and given special markings. This also applies to narcotics and psychotropic which has entered an expiration time ${ }^{[12]}$. Narcotics and psychotropic preparations that have expired will generally have changes in physical, chemical, microbiological, therapeutic and toxicological specifications, so they are not safe for consumption by patients. 


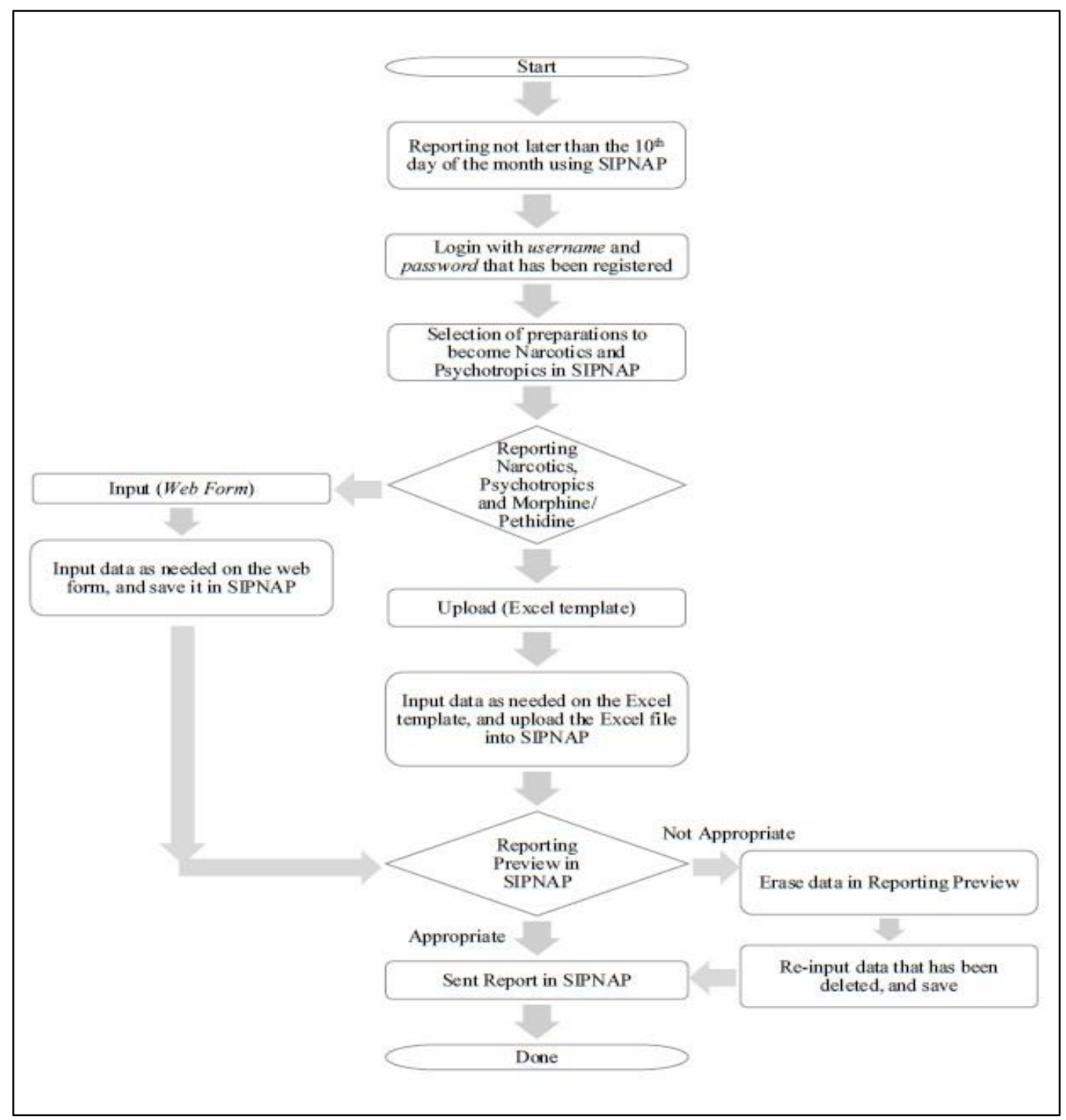

Figure 2. Narcotics and Psychotropics Reporting Flowchart using SIPNAP

In the time, when narcotics and psychotropics have been damaged, such as leakage in rectal tube preparations, narcotics and psychotropics will be collected first. The responsible pharmacist of pharmacy will contact the pharmaceutical distributors who distributes the drug for returns. The narcotics and psychotropic returns process must be completed with a valid handover document with a photocopy of the purchase invoice file. If the return process cannot be carried out, the pharmacy will carry out the destruction of narcotics and psychotropic that are damaged by the procedure according to the law ${ }^{[4]}$.

Sixth, inventory stock of narcotics and psychotropic. Observation results show that the five pharmacies $(100 \%)$ have implemented a system of inventory stock related to narcotics and psychotropic supplies in pharmacies. Inventory stock in the process of storing narcotics and psychotropic will be different from storing pharmaceutical preparations in general. In pharmaceutical preparations, the inventory 
stock is carried out at least once in 6 (six) months, while in narcotics and psychotropic at least once in 1 (one) month. In some pharmacies that were observed, the time of execution of inventory stocks generally varied, starting from routine implementation every day, to routine implementation every month. Inventory stock will be an illustration to assess the smoothness in the process of storing and recording narcotics and psychotropic, so that the recording data on card stock with the amount of physical stock of narcotics and psychotropic must be appropriate. Loss analysis can be carried out if a discrepancy is found between the amount of physical stock and the recording on the stock card ${ }^{[14]}$. In addition, the inventory stock will play an accurate role in the internal control process of narcotics and psychotropic inventories in pharmacies in order to avoid shortages (stocks) of narcotics and psychotropic drugs, or the potential for preparations to become narcotics and psychotropic that are damaged and/or out of date but still stored in the same place as the finished preparations in good condition.

Seventh, narcotics and psychotropic reporting. Observation results showed that the five pharmacies (100\%) have implemented a narcotics and psychotropic reporting system electronically using SIPNAP. This was in accordance with the Regulation of The Minister of Health of The Republic of Indonesia Number 3 of 2015 on Circulation, Storage, Destruction, and Reporting of Narcotics, Psychotropic and Pharmacy Precursors in Article 45 Section 6 and 9. In Section 6, it states that "Pharmacy, Hospital Pharmacy Installation, Clinical Pharmacy Installation, Scientific Institution, and individual practicing physicians are required to make, store and submit reports on income and submission/use of narcotics and psychotropics, every month to The Head of The Regency/City Health Service with a copy to The Head of The Local Balai". Also, Section 9 states that "Reports can use narcotics, psychotropic and/or pharmaceutical precursor reporting systems electronically"[4].

An important role of SIPNAP in reporting is to improve accuracy and compliance in reporting the use of narcotics and psychotropic ${ }^{[15]}$. SIPNAP has several integrated parts, namely health service units, district/city health offices, provincial and national health offices, and web servers. SIPNAP can be accessed by computer media connected to the internet through the website http://sipnap.binfar.depkes.go.id using a username and password that has been registered previously. Each pharmacy will first download the report format of narcotics or psychotropic usage in the form of an excel template through the narcotics import menu or psychotropics import. The pharmacy will then fill out the report according to the specified format, then submit it to the SIPNAP program through the import menu, the narcotics import submenu or the psychotropics import. Narcotics and psychotropic reporting can also be done by filling in directly on the SIPNAP web form ${ }^{[16]}$.

The key to the success of the narcotics and psychotropic reporting process by the pharmacy is compliance and completeness in narcotics and psychotropic reporting. This is confirmed in the Regulation of The Minister of Health of The Republic of Indonesia Number 3 of 2015 on Circulation, Storage, Destruction, and Reporting of Narcotics, Psychotropics and Pharmacy Precursors in Article 45 Section 7 and 10. In Section 7 states that "Reporting by Pharmacy, Hospital Pharmacy Installation, Clinical Pharmacy Installation, Scientific Institution, and individual practicing physicians at least contains of the name, dosage form, and strength of narcotics, psychotropics, and/or pharmacy precursors; the amount of stocks at the beginning and end of month; the amount received; and the amount consigned". Section 10 states that 
"Report is submitted not later than the $10^{\text {th }}$ day of the month"[4].

The fulfillment and completeness in narcotics and psychotropic reporting has been carried out by all pharmacy that were observed (100\%). The narcotics and psychotropics reporting process through SIPNAP by each pharmacy is carried out not close to the date specified in the legislation, this aims to prevent down servers or errors on the website used and have an impact on the process of narcotics and psychotropic reporting with SIPNAP. Reporting compliance with SIPNAP in several pharmacies in Denpasar City is also supported by the presence of trained human resources who have participated in previous training on a regular and ongoing basis in using the SIPNAP website. Trained human resources will speed up the process of sending SIPNAP reports to the central authorities $^{[17]}$.

The completeness in reporting process with SIPNAP, which was a minimum prerequisite, has been fulfilled in each pharmacies observed. Specifically, certain narcotic preparations containing morphine or pethidine such as the continus morphine sustainability tablet have special features in Reporting through SIPNAP. In morphine reporting, completeness of supporting data in the form of total expenditure, patient's name, patient's address, date given, number of products given, doctor's name, doctor's address, and residual expenses must be reported and included in the form in the excel format specified to be subsequently entered into the program SIPNAP ${ }^{[19]}$. Morphine is classified as narcotics group II which can be given by prescription but has a high enough potential to cause dependence on its users. ${ }^{[18]}$ This will cause the use of morphine to be closely monitored to prevent various health risks and dependence on the abuse of the use of morphine.

\section{CONCLUSION}

From this study, the majority of pharmacies $(100 \%)$ have implemented narcotics storing and reporting practices in accordance to the applicable laws and regulations. Observed pharmacies both network pharmacies and independent pharmacies have implemented narcotics and psychotropics storing systems using special cabinets, the use of the FIFO and FEFO systems in narcotics and psychotropics expenditures, the use of both manual and electronic stock cards, separation of expired drugs and invetory stock. Observed pharmacies have also carried out narcotics and psychotropic report using the SIPNAP system. The responsible pharmacist must always evaluate the storage and reporting of narcotics and psychotropic in the pharmacy to guarantee quality and maintain suitability of the pharmaceutical services process according to established standards. The writer hope that in further research, it can be explored more widely how the implementation of storing and reporting narcotics and psychotropics at other pharmacies in Denpasar City or Bali Province, so that it can better reflect the storing and reporting conditions of narcotics and psychotropics in pharmacies located in Bali Province.

\section{CONFLICT OF INTEREST}

All authors state that no financial or personal relationships with other people or organizations that could inappropriately influence this paper.

\section{ACKNOWLEDGEMENT}

Thank you to all parties from the Department of Pharmacy, Faculty of Math and Science, Udayana University, a Faculty of Pharamcy, Universitas Gadjah Mada along with several pharmacies in the Denpasar City area who have provided a lot of assistance in all part of this research process. 


\section{REFERENCE}

1. Anderson P. D. The Broad Field of Forensic Pharmacy. Journal of Pharmacy Practice. 2012; 25 (1): 7-12.

2. Dahiya S., Dahiya R., Lodhi N. K., Shrivastava S. K., and Soni L. PatientOriented Pharmacy Education and Redefining Role of Pharmacist: A Challenge to Educationists. Bulletin of Pharmaceutical Research. 2012, 2 (3): 154-158.

3. Menteri Kesehatan Republik Indonesia. Peraturan Menteri Kesehatan Republik Indonesia No. 73 Tahun 2016 Tentang Standar Pelayanan Kefarmasian di Apotek. Jakarta: Kementerian Hukum dan Hak Asasi Manusia Republik Indonesia; 2017.

4. Menteri Kesehatan Republik Indonesia. Peraturan Menteri Kesehatan Republik Indonesia No. 3 Tahun 2015 Tentang Peredaran, Penyimpanan, Pemusnahan, dan Pelaporan Narkotika, Psikotropika, dan Prekursor Farmasi. Jakarta: Menteri Hukum dan Hak Asasi Manusia Republik Indonesia; 2015.

5. Lumenta J. T., Wullur A. C., dan Yamlean P. V. Y. Evaluasi Penyimpanan dan Distribusi Obat Psikotropika di Rumah Sakit Jiwa Prof. Dr. V. L. Ratumbuysang Manado. Pharmacon. 2015; 4 (4): 147-155.

6. Asyikin H. A. Studi Implementasi Sistem Penyimpanan Obat Berdasarkan Standar Pelayanan Kefarmasian di Apotek Sejati Farma Makassar. Media Farmasi. 2018; 14 (1): 29-34.

7. WHO. WHO Technical Report Series: Annex 9, Guide to Good Storage Practice for Pharmaceuticals. No. 908. Geneva: World Health Organization; 2003.

8. Kemenkes RI. Farmakope Indonesia. Edisi V. Jakarta: Kementerian Kesehatan Republik Indonesia; 2015.
9. Yuda P. E. S. K., dan Suena N. M. D. S. Pengaruh Suhu Penyimpanan Terhadap Kadar Tablet Vitamin C Yang Diukur Menggunakan Metode Spektrofotometri Uv-Vis. Medicamento. 2016; 2 (1): 23-27.

10. Wigati A. Laporan Praktik Kerja Profesi Apoteker di Apotek Sammarie Basra Jl. Basuki Rahmat No. 31 Jakarta Timur Periode 6 Oktober-1 November 2014. Depok: Fakultas Farmasi, Program Profesi Apoteker, Universitas Indonesia; 2015.

11. Soraya W. R. Perbandingan Proses Pengadaan Obat di Apotek Sanata Dharma dan Apotek K-24 di Yogyakarta Tahun 2015. Skripsi. Yogyakarta: Fakultas Farmasi, Universitas Sanata Dharma, Yogyakarta; 2015.

12. Kemenkes RI. Petunjuk Teknis Standar Pelayanan Kefarmasian di Apotik. Jakarta: Kementerian Kesehatan Republik Indonesia; 2019.

13. Karnila A. Laporan Praktek Kerja Profesi Apoteker di Kementerian Kesehatan Republik Indonesia, di PT Bintang Toedjoe, dan di Apotek Atrika. Depok: Fakultas Farmasi, Program Profesi Apoteker, Universitas Indonesia; 2012.

14. Satrianegara F., Syarfaini, Adha S., dan Husain N. I. Gambaran Pengelolaan Persediaan Obat di Gudang Farmasi RSUD Syekh Yusuf Gowa. Al-Sihah: Public Health Journal. 2018; 10 (2): 180-191.

15. Putri D. K., Pribadi P., and Setiawan A. The Evaluation of Narcotic and Psychotropic Reporting Systems (SIPNAP). Advances in Social Science, Education, and Humanities Research. 2020; 436 (1): 1212-1216.

16. Farhan I. Laporan Praktek Kerja Profesi Apoteker di Apotek Kimia Farma No. 55 Jalan Kebayoran Lama No. 34K Jakarta Selatan Periode 03 April-10 Mei 2014. Depok: Fakultas 
Farmasi, Program Profesi Apoteker, Universitas Indonesia; 2014.

17. Setiani N. Laporan Praktek Kerja Profesi Apoteker di Direktorat Bina Produksi dan Distribusi Kefarmasian, Direktorat Jenderal Bina Kefarmasian dan Alat Kesehatan, Kementerian Kesehatan Republik Indonesia Periode 16 Januari-27 Januari 2012. Depok: Fakultas Farmasi, Program Profesi Apoteker, Universitas Indonesia; 2012.

18. Menteri Kesehatan Republik Indonesia. Peraturan Menteri Kesehatan Republik Indonesia No. 44 Tahun 2019 Tentang Perubahan Penggolongan Narkotika. Jakarta: Kementerian Hukum dan Hak Asasi Manusia Republik Indonesia; 2019.

19. Kemenkes RI. SIPNAP: User Manual untuk Apotek. Jakarta: Kementerian Kesehatan Republik Indonesia; 2014.

20. Ratri F. B. Laporan Praktek Kerja Profesi Apoteker di Apotek Kimia Farma No. 48 Jl. Matraman Raya No. 55 Jakarta Timur Periode 02 Januari 14 Februari 2014. Depok: Fakultas Farmasi Program Profesi Apoteker Universitas Indonesia; 2014.

21. Pauziah F. Laporan Praktek Kerja Profesi Apoteker di Rumah Sakit Umum Pusat Fatmawati Cilandak, Jakarta Selatan Periode 1 Juli - 31 Agustus 2013. Depok: Fakultas Farmasi Program Profesi Apoteker Universitas Indonesia; 2014.

22. Kemenkes RI. Infodatin Pusat Data dan Informasi Kementerian Kesehatan RI: Anti Narkoba Sedunia 26 Juni'17. Jakarta: Kementerian Kesehatan Republik Indonesia; 2017.

23. Puslitdatin BNN. Data Statistik Kasus Narkoba. Jakarta: Pusat Penelitian, Data dan Informasi Badan Narkotika Nasional Republik Indonesia [cited 2020 August 3]. Available from: https://puslitdatin.bnn.go.id/portfolio/d ata-statistik-kasus-narkoba/. 